\title{
Effectiveness of Dental Health Education Intervention Using the 16-Surface Tooth Brushing Program Among 7-9-Year-Old Schoolchildren in Indonesia
}

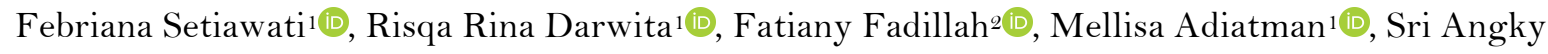 \\ Soekanto ${ }^{3}$, Gita Ariffa Sjarkawi1(1)
}

${ }^{1}$ Department of Dental Public Health and Preventive Dentistry, Faculty of Dentistry, Universitas Indonesia, Jakarta, Indonesia.

2Undergraduate Program, Faculty of Dentistry, Universitas Indonesia, Jakarta, Indonesia.

${ }^{3}$ Department of Oral Biology, Faculty of Dentistry, Universitas Indonesia, Jakarta, Indonesia.

Author to whom correspondence should be addressed: Risqa Rina Darwita, Department of Dental Public Health and Preventive Dentistry, Faculty of Dentistry, Universitas Indonesia, Salemba Raya No. 4, Jakarta, 10430, Indonesia. Phone: +6281298773359. E-mail: risqarina2008@gmail.com.

Academic Editor: Alessandro Leite Cavalcanti

Received: 12 February 2020 / Accepted: 25 June 2020 / Published: 22 July 2020

How to cite this article: Setiawati F, Darwita RR, Fadillah F, Adiatman M, Soekanto SA, Sjarkawi GA. Effectiveness of dental health education intervention using the 16-surface tooth brushing program among 7-9-year-old schoolchildren in Indonesia. Pesqui Bras Odontopediatria Clín Integr. 2020; 20:e5698. https://doi.org/10.1590/pboci.2020.144

\begin{abstract}
Objective: To determine the effect of dental health education for teachers and parents on children aged 7-9 years old. Material and Methods: This was a quasi-experimental study with a nonrandomized control group and a pretest-posttest design. The intervention group comprised 20 teachers and 66 mothers, whereas the control group consisted of 10 teachers and 54 mothers. Data on the knowledge and behavior of teachers and mothers were retrieved by pretest and posttest questionnaires. The 66 children in the intervention group underwent a 16 -surface tooth brushing program, whereas the 54 children in the control group were only provided theoretical education by their teachers and mothers. The evaluation was conducted after one month to measure the children's dental plaque index. Results: An increase in teachers' oral health knowledge (16.7\%), teachers' oral health behavior (20\%), mothers' oral health knowledge $(16.7 \%)$, and mothers' oral health behavior $(20 \%)$ was noted; the children's plaque index was decreased (47\%). Conclusion: The dental health education of teachers and parents (mothers) supported by the 16surface teeth brushing program resulted in a significant reduction in the dental plaque index in children aged 7-9 years old.
\end{abstract}

Keywords: Health Education, Dental; Oral Health; Health Knowledge, Attitudes, Practice. 


\section{Introduction}

Oral health is an important aspect of an individual's life because it is the main route of entrance for bacteria and viruses into the body [1]. Dental caries is one of the most common diseases of the oral cavity. It is a multifactorial disease [2], and one of the contributing factors is dental plaque, which is a soft layer consisting of a community of microorganisms attached to the tooth surface [3]. The plaque can be measured using a plaque index on a scale of $0-3$ [4].

Based on the Basic Health Research (2007, 2013), the national prevalence of oral and dental problems increased from 23.2\% in 2007 to 25.9\% in 2013. In 2018, based on Basic Health Research data, the prevalence increased to $88.8 \%$ [5]. Furthermore, the proportion based on the characteristics of children aged 7-9 years increased from $21.6 \%$ in 2007 to $28.9 \%$ in 2013 in Indonesia, and from $26.6 \%$ to $31.4 \%$ in the province of DKI Jakarta. Based on data from Basic Health Research (2018), the prevalence of dental caries in 5-9-year-old children in Indonesia was $92.6 \%$ [5].

In an effort to prevent dental caries in children, it is important to increase awareness regarding oral hygiene and its maintenance. The role of teachers and parents is significant in this matter. The formation of these behaviors begins from the cognitive or knowledge domain, one of which is through education [1]. Dental health education is a learning process aimed at individuals and groups of society to achieve the highest degree of dental health and increase public understanding and awareness of the importance of maintaining dental and oral health [6]. During the education process, changing one's perception of individuals or groups of people gains knowledge and experience through various kinds of educational aids. According to the previous authors, demonstration acts as a high-intensity tool that aids in the perception of the education provided; besides, the absorption of oral health knowledge will improve the brushing teeth [1].

Brushing teeth is a mechanical method used for removing plaque that causes dental caries. The effectiveness of tooth brushing in removing the dental plaque is influenced by several factors such as the method and time of tooth brushing, the willingness to brush the teeth, and the size of a toothbrush [7]. There are several methods to brush the teeth, but the most important thing is to remove the plaque from all the 16 surfaces of the teeth. It is difficult for children to brush all the surfaces of the teeth properly.

Few studies have evaluated the extent of tooth brushing on all the 16 surfaces of the teeth in school children. Thus, this study aimed to determine the effect of dental health education (DHE) on teachers and parents (mothers) concerning the 16-surface tooth brushing program in children aged 7-9 years.

\section{Material and Methods}

Study Design and Sampling

In this quasi-experimental study comprising a nonrandomized control group design, the pretestposttest consisted of two groups: intervention and control. This study was conducted at the Cipinang Besar Utara Elementary School o9 Pagi and the Nurul Yaqin Elementary School in Cipinang, Pulogadung District, East Jakarta, over three months. The students at the Cipinang Besar Utara Elementary School belonged to the intervention group, while those at the Nurul Yaqin Elementary School belonged to the control group.

The sampling technique used was purposive sampling; a minimum sample size calculation was obtained using the Slovin formula [8]. The minimum sample size was 20 teachers and 66 pairs of parents (mothers) and children in the intervention group and 10 teachers and 54 pairs of parents (mothers) and children in the control group. 


\section{Data Collection}

An educational program regarding tooth brushing (16-surface tooth brushing program) was provided to the treatment group at the school once a week. The children in the control group received theoretical education, which was provided by their teachers and mothers. A questionnaire was filled out by the teachers and mothers to determine the level of knowledge and behavior toward the children's oral health before and after education in the form of counseling. The Silness-Loe plaque index was used to evaluate the children before and after the education program.

\section{Statistical Analysis}

The comparison between the control group and intervention group of knowledge and behavior of teachers, knowledge, and behaviors of parents (mothers) and children's plaque index were analysed using parametric and non-parametric tests (Wilcoxon Signed Rank test, Mann-Whitney U-test, and T-Test). The pvalue $<0.05$ was considered as statistically significant.

\section{Ethical Aspects}

This study was approved by the Research and Bioethics Committee of the Faculty of Dentistry, Universitas Indonesia (Protocol No. 010560618) and was conducted in full accordance with the World Medical Association Declaration of Helsinki. All respondents agreed to participate by signing informed consent.

\section{Results}

The results of the normality test revealed that the distribution of the data was not normal. No significant differences in the pretest $(\mathrm{p}=0.115)$ and posttest $(\mathrm{p}=0.073)$ knowledge were observed between the two groups (Table 1). Comparisons of the pretest and posttest knowledge between the two groups using the non-parametric Wilcoxon Signed Rank test demonstrated significant differences in teachers' knowledge between the intervention group $(\mathrm{p}=0.001)$ and the control group $(\mathrm{p}=0.006)$ (Table 1).

Table 1. Comparison of teachers' knowledge regarding oral and dental health before and after dental health education.

\begin{tabular}{lccc}
\hline \multicolumn{1}{c}{ Knowledge Group } & Pretest & Posttest & p-value \\
\hline Intervention $(\mathrm{n}=15)$ & $6(4-7)$ & $7(7-8)$ & $0.001^{*}$ \\
Control $(\mathrm{n}=10)$ & $5(3-6)$ & $6.5(6-8)$ & $0.006^{*}$ \\
\multicolumn{1}{c}{ p-value } & 0.115 & 0.073 & \\
\hline \#Mann-Whitney Utest, *Statistically Significant & &
\end{tabular}

\#Mann-Whitney U test; *Statistically Significant.

As shown in Table 2, no significant differences in the pretest $(p=0.268)$ and posttest $(p=0.176)$ behaviors between the intervention and control groups were noted. The comparison results in the intervention and control groups revealed significant differences in teachers' behavior between the intervention $(p=0.021)$ and control $(\mathrm{p}=0.025)$ groups (Table 2$)$.

Table 2. Comparison of teachers' behavior on oral health before and after given dental health education.

\begin{tabular}{lccc}
\hline \multicolumn{1}{c}{ Knowledge Behavior Group } & Pretest & Posttest & p-value $^{\#}$ \\
\hline Intervention $(\mathrm{n}=15)$ & $5(4-6)$ & $6(4-7)$ & $0.021^{*}$ \\
Control $(\mathrm{n}=10)$ & $4.5(2-6)$ & $5(3-7)$ & $0.025^{*}$ \\
\multicolumn{1}{c}{$\mathrm{p}$-value } & 0.268 & 0.176 & \\
\hline
\end{tabular}

\#Wilcoxon Signed-Rank test; *Statistically Significant. 
As seen in Table 3, significant differences in the pretest $(\mathrm{p}=0.002)$ and posttest $(\mathrm{p}=0.001)$ values for knowledge were observed between the intervention and control groups. Likewise, significant differences between the pretest and posttest knowledge values in the intervention $(p=0.001)$ and control $(p=0.001)$ group were observed.

Table 3. Comparison of maternal knowledge in the intervention and control groups before and after dental health education.

\begin{tabular}{|c|c|c|c|c|c|c|c|c|c|}
\hline \multicolumn{10}{|c|}{ Knowledge } \\
\hline \multirow[t]{3}{*}{ Groups } & \multicolumn{4}{|c|}{ Good } & \multicolumn{4}{|c|}{ Not Good } & \multirow[t]{3}{*}{ p-value* } \\
\hline & \multicolumn{2}{|c|}{ Pretest } & \multicolumn{2}{|c|}{ Posttest } & \multicolumn{2}{|c|}{ Pretest } & \multicolumn{2}{|c|}{ Posttest } & \\
\hline & $\mathrm{N}$ & $\%$ & $\mathrm{~N}$ & $\%$ & $\mathrm{~N}$ & $\%$ & $\mathrm{~N}$ & $\%$ & \\
\hline Intervention & 63 & 95.5 & 66 & 100.0 & 3 & 4.5 & $\mathrm{O}$ & 0.0 & $0.001^{*}$ \\
\hline Control & 43 & 79.6 & 54 & 100.0 & 11 & 20.4 & $\mathrm{O}$ & 0.0 & $0.001^{*}$ \\
\hline p-value & \multicolumn{4}{|c|}{$0.002^{*}$} & \multicolumn{4}{|c|}{$0.001^{*}$} & \\
\hline
\end{tabular}

*Wilcoxon Signed-Rank test; *Statistically Significant.

There were no significant differences in the pretest behavior values between the intervention group and the control group, whereas, in the case of the posttest behavior values, a significant difference was observed between the two groups $(\mathrm{p}<0.05)$. There were indicated significant differences between the mother's behavior in the intervention group compared to control group ( $\mathrm{p}<0.001)$ (Table 4$)$.

Table 4. Comparison of mothers' behavior on oral and dental health in the intervention and control groups before and after dental health education.

\begin{tabular}{|c|c|c|c|c|c|c|c|c|c|}
\hline \multicolumn{10}{|c|}{ Behavior } \\
\hline \multirow[t]{3}{*}{ Groups } & \multicolumn{4}{|c|}{ Good } & \multicolumn{4}{|c|}{ Not Good } & \multirow[t]{3}{*}{ p-value posttest } \\
\hline & \multicolumn{2}{|c|}{ Pretest } & \multicolumn{2}{|c|}{ Posttest } & \multicolumn{2}{|c|}{ Pretest } & \multicolumn{2}{|c|}{ Posttest } & \\
\hline & $\mathrm{N}$ & $\%$ & $\mathrm{~N}$ & $\%$ & $\mathrm{~N}$ & $\%$ & $\mathrm{~N}$ & $\%$ & \\
\hline Intervention & 59 & 89.4 & 66 & 100.0 & 7 & 10.6 & 0 & 0.0 & $0.001^{*}$ \\
\hline Control & 51 & 94.4 & 54 & 100.0 & 3 & 5.6 & 0 & 0.0 & $0.001^{*}$ \\
\hline p-value pretest & \multicolumn{4}{|c|}{0.767} & \multicolumn{4}{|c|}{$0.023^{*}$} & \\
\hline
\end{tabular}

*Statistically Significant.

The final plaque index of the children in the intervention group ranged between 0.04-1.96 (Table 5). The highest frequency in the intervention group was 1.00-1.90, which was defined as the middle category and seen in 40 children (60.6\%), while the remaining 26 children $(39.4 \%)$ had a plaque index of $0.10-0.90$ (which was defined as the decent category). Thus, an increase in the number of children in the decent oral hygiene category was observed. The initial plaque index of children in the control group ranged from 0.33-3.00. The highest frequency in the control group was 2.00-3.00 (bad category) and was observed in 35 children (64.8\%), while the remaining 24 children $(44.4 \%)$ with a plaque index of $1.00-1.90$ (middle category). Thus, a decrease in the number of children belonging to the decent category was observed.

Table 5. Frequency distribution of children's plaque index in the intervention and control groups after the 16-surface tooth brushing program.

\begin{tabular}{ccccc}
\hline & \multicolumn{3}{c}{ Intervention } & Control \\
Plaque Index & $\mathrm{N}$ & $\%$ & $\mathrm{~N}$ & $\%$ \\
\hline 0.00 & 0 & 0.0 & 0 & 0.0 \\
$0.10-0.90$ & 26 & 39.4 & 0 & 0.0 \\
$1.00-1.90$ & 40 & 60.6 & 24 & 44.4 \\
$2.00-3.00$ & 0 & 0.0 & 30 & 55.6 \\
Total & 66 & 100.0 & 54 & 100.0 \\
\hline
\end{tabular}


The independent t-test revealed no significant differences in the initial plaque index between the intervention group and the control group $(\mathrm{p}=0.571)$, whereas a significant difference in the final plaque index was observed between the two groups $(\mathrm{p}=0.001)$ (Table 6). A significant difference between the initial and final plaque index was noted in the intervention group $(\mathrm{p}=0.001)$ but not in the control group $(\mathrm{p}=0.670)$.

\begin{tabular}{|c|c|c|c|}
\hline & Initial Plaque Index & Final Plaque Index & \\
\hline Groups & Mean $(\mathrm{SD})$ & Mean $(\mathrm{SD})$ & p-value \\
\hline Intervention $(\mathrm{n}=66)$ & $2.1479 \pm 0.4948$ & $1.1382 \pm 0.4802$ & $0.001^{*}$ \\
\hline Control $(\mathrm{n}=54)$ & $2.0844 \pm 0.6875$ & $2.1100 \pm 0.5727$ & 0.670 \\
\hline p-value & 0.571 & $0.001^{*}$ & \\
\hline
\end{tabular}

\section{Discussion}

In the present study, the scores for the knowledge of teachers in the intervention group significantly increased after the education program. Likewise, the median value of the teacher's behavior in the intervention group was significantly increased after the program; similar increases were seen in the control groups. This is because the teachers in both groups received education about the importance of maintaining the children's oral and dental health.

According to previously reported results, the respondents' behavior increased from the increasing process of knowledge from dental health education [9]. This is also in accordance with previous research, which has shown that if the information is provided to the school teachers, an improvement in knowledge, behaviors, and actions is generally observed. This can happen because the teacher has a positive behavior toward oral health education for students as part of the teaching curriculum. After the teacher was given the training that was impact on the oral hygiene of his students was $18.5 \%$ [10].

In addition, a study on the influence of lectures and demonstrations on behavior concluded that the effect of education on knowledge was due to a combination of lecture, demonstration, and question and answer methods that could increase the respondents' knowledge [11]. Some authors have also stated that counseling with lectures and question and answer methods with leaflet kits can increase the respondents' knowledge [12].

In this study, the three methods were combined. The lecture method was used as a tool in the form of a PowerPoint presentation. Booklets containing material about children's oral and dental health, which was packaged in such a way that it was easy to understand and supported by pictures and videos, was provided. In the demonstration method, we used a teaching kit in the form of a dental phantom and toothbrush. After the counseling, a question and answer session was conducted so that the respondents could understand more about the material provided.

The mothers' median knowledge and behavior significantly increased after the education program in the intervention and control groups. This is because the parents (mothers) in both groups received education on the importance of maintaining the oral and dental health of their children. These results are in accordance with previous findings, showing an increase in the knowledge, behaviors, and behavior about oral and dental health in parents after training/counseling [7]. Parents' knowledge can be obtained naturally or via planning through an educational program.

According to the results of previous research, the increase of knowledge would affect the increase of the behavior [9]. It showed a significant relationship between mothers' knowledge and behaviors and the 
children's plaque index [13]. The children of mothers with knowledge about dental and oral health have a decent plaque index. In another study, a significant relationship between knowledge and mothers' behaviors was noted [14]. This shows that parents, especially mothers, have a very important influence on the maintenance of the children's health and dental hygiene.

The average plaque index of the intervention group was decreased from 2.15 in the bad category to 1.14 in the middle category $(\mathrm{p}<0.05)$. This shows that the children in the intervention group understood and practiced the proper tooth brushing technique. This study's results are comparable to those obtained previously, which showed a significant relationship between tooth brushing's mass activity and the decrease in plaque index [15].

Some authors evaluated the role of 21 days of education on tooth brushing in children aged 5-8 years in the Pembeliangan Village of North Kalimantan and reported a decrease in plaque index after the subjects the education program [9]. In the control group, the tooth brushing activity was not held in the school; instead, it was limited to the education of how to brush teeth properly and properly by parents (mothers) at home and teachers at school, as well as children's report cards. The average plaque index of the control group has seen an increase from 2.08 in the bad category to 2.11 and remains in the bad category ( $>0.05)$, it can be said that there are no significant differences between the initial and final children's plaque index. This increase was due to a lack of awareness of children affected by mothers' role as parents and teachers.

Children's habits can also influence this condition in consuming foods and beverages that contain a high level of sugar. Based on the previous research results, it should not only teach children how to brush their teeth with theory but also be practiced directly in the intervention group. In Table 6, it can be seen that the initial plaque indices between the intervention and control groups were not significantly different. This may be because the subjects in both groups had the same knowledge at the initial examination, due to the absence of education through teachers and parents [16].

\section{Conclusion}

A significant decrease in the dental plaque index was noted in schoolchildren aged 7-9 years following the provision of DHE (16-surface tooth brushing program) to the teachers and parents.

\section{Authors' Contributions}

\begin{tabular}{|c|c|c|}
\hline FS & (iD) $0000-0001-8515-2369$ & Investigation and Formal Analysis. \\
\hline $\mathrm{RRD}$ & (iD) $0000-0001-7480-7876$ & $\begin{array}{l}\text { Conceptualization, Methodology, Writing - Original Draft Preparation and } \\
\text { Funding Acquisition. }\end{array}$ \\
\hline $\mathrm{FF}$ & (iD) $0000-0002-8369-1147$ & Validation. \\
\hline MA & (iD) 0000-0002-9399-9305 & Writing - Review and Editing and Supervision. \\
\hline SAS & (iD) $0000-0001-6812-2424$ & Writing - Review and Editing. \\
\hline GAS & (iD) $0000-0001-5228-9027$ & Visualization. \\
\hline
\end{tabular}

\section{Financial Support}

The Directorate of Research and Community Service of Universitas Indonesia.

\section{Conflict of Interest}

The authors declare no conflicts of interest. 


\section{References}

[1] Notoatmodjo S. Basic Principles in Public Health Science. Jakarta: Rineka Cipta Publisher; 2003. p. 57-65.

[2] Mount GJ, Hume WR, Ngo HC, Wolff MS. (Editors). Preservation and Restoration of Tooth Structure. 3rd. ed. London: John Wiley \& Sons, Inc.; 2016. 328pp.

[3] Kidd EAM. Essentials of Dental Caries: The Disease and its Management. 3rd. ed. Oxford: Oxford University Press; 2005. 192pp.

[4] Newman MG, Takei HH, Klokkevold PR, Carranza FA. Carranza’s Clinical Periodontology. 12th ed. Philadelphia: Elsevier; 2015.

[5] Ministry of Health Republic of Indonesia. Basic Health Research (RISKESDAS). Jakarta; 2018.

[6] Wahyuni HN, Darwita RR, Adiatma M. Empowering preschool teachers in motivating mothers to brush teeth of children 36-71 months. AIP Conference Proceedings 2019; 2092(1):040015. https://doi.org/10.1063/1.5096748

[7] Amin M, Nyachhyon P, Elyasi M, Al-Nuaimi M. Impact of an oral health education workshop on parents' oral health knowledge, attitude, and perceived behavioral control among African immigrants. J Oral Dis 2014; 2014:1-7. https://doi.org/10.1155/2014/986745

[8] Ansar, Lukum A, Arifin, Dengo YJ. The influence of school culture on the performance of high school English teachers in Gorontalo province. Int J Educ Res 2017; 5(10):35-47.

[9] Darwita RR, Gityawati C, Andreas P, Setiawati, F, Soekanto SA. The role of education for 21 days in improving the effectiveness of brushing teeth of children age $5-8$-year-old in Pembeliangan Village North Kalimantan. J Int Dent Med Res 2017; 10:683-8.

[10] Davies RM, Davies GM, Ellwood RP, Kay EJ. Prevention. Part 4: toothbrushing: what advice should be given to patients? Br Dent J 2003; 195(3):135-41. https://doi.org/10.1038/sj.bdj.4810396

[11] Renyelle SS, Alexandre B, Ramona FCT. Dental health education: a literature review. Rev Odonto Cienc 2014; 29(1):18-26.

[12] Cahyaningsih I, Wiedyaningsih C, Kristina SA. Effect of education on the level of community knowledge about analgesics in Cangkringan, Sleman regency, Yogyakarta. Mutiara Medika 2013; 13(2):98-104.

[13] Guswan G, Yandi S. Relationship of mother's knowledge and practice towards the children's plaque index in Ibnu Akbar kindergarten of the city of Padang. Jur Ked Gigi 2017; 29(3):164-67.

[14] Zia HK, Nurhamidah N, Afriza D. Hubungan pengetahuan, sikap dan perilaku ibu terhadap kebiasaan menyikat gigi anak. J B-Dent 2014; 1(1):43-8. [In Indonesian].

[15] Fahrina F. Efektivitas Sikat Gigi Massal Untuk Menurunkan Indeks Plak pada Siswa Kelas I-V MI Muhammadiyah Trangsan. Jurnal Ilmu Kedokteran Gigi 2017; 1(2). [In Indonesian].

[16] Riznika R, Adhani R, Oktiani BW, Hatta I. Differences in plak index scores before and after demanding with video media and study model. Dentino Jur Ked Gigi 2017; 2(1):44-9. 